\title{
SPROUTED ZEA MAYS ON DATE PALM LEAVES AND POTATOES PEEL WASTE MIXTURE AND ITS EFFECTS ON PERFORMANCE OF DESERT GOATS UNDER DRY SEASON IN SINAI. \\ Helal, H. G. and Mona M. Hassan \\ Department of Animal \& Poultry Nutrition, Desert Research Center, Mataria, Cairo, Egypt \\ *Corresponding author:godahassan@yahoo.com
}

\begin{abstract}
The objectives of this study were to evaluate Sprouted techniques by planting white corn seeds (Zea Mays L.) on four roughage mixtures of date palm leaves (Phoenix dactylifera L.) and potatoes peels waste (Solanum tuberosum). Twenty five desert male goats averaged (eighteen months old) $22.76 \pm 1.29 \mathrm{~kg}$ live body weight were divided randomly into five equal groups (5 animals each) to receive one of the following experimental roughages R1: alfalfa (Medicago sativa) hay (control), R2: $75 \%$ potatoes peel waste (PPW) $+25 \%$ date palm leaves (DPL), R3: $50 \%$ potatoes peel waste (PPW) $+50 \%$ date palm leaves (DPL), R4: $25 \%$ potatoes peel waste (PPW) $+75 \%$ date palm leaves (DPL) and R5: $100 \%$ date palm leaves (DPL). Goats were used in feeding trial lasted about fourty five days. The metabolism trial was conducted after the feeding trial to get the most nutritious sprouts green fodder (SGF) with concentrate feed mixture (CFM).

Results showed that sprouting corn seeds on potatoes peel waste (PPW) and date palm leaves (DPL) as a media had increased CP, EE, C.CHO and ash contents while decreased OM, CF, NDF and ADF contents as compared with none sprouted media. Sprouted corn seeds on PPW or DPL revealed a significant $(P \leq 0.05)$ improvement in digestibility coefficients of DM, EE and C.CHO. Nutritive values expressed as TDNg/Kg B.W. and DCP\% increased significantly $(P \leq 0.05)$ in sprouted mixtures as compared with control $(R 1)$. Goats fed R3 had $(P \leq 0.05)$ lowest total feed intake and highest digestibility coefficients of DM, CP, EE, C.CHO and DCP. Also, goats fed the treated mixture $R 3$ retained higher $(P \leq 0.05)$ nitrogen values and nitrogen intake comparable with other studied groups. Goats fed sprouted mixtures had improved $(\mathrm{P} \leq 0.05)$ values of total water intake and decreased urinary water execration. Sprouted corn seeds had improved $\mathrm{Na}$ and $\mathrm{K}$ balances ( $\mathrm{g} / \mathrm{kg} \mathrm{BW}$ ) as compared with control group (R1). Goats fed sprouted mixtures had significantly higher $(P \leq 0.05)$ values of total volatile fatty acids (VFA), ruminal ammonia (NH3- N), serum total proteins, albumin, globulin, urea and creatinin compared with control group.

In conclusion we can produce green fodder by utilizing dried potatoes peel waste (PPW) and date palm leaves (DPL) as a media mixture (50\% PPW and 50\% DPL) by simple methodology using sprouts corn without any harmful effect on desert goats under dry season.

Keywords: Sprouted corn seeds, date palm leaves, potatoes peel waste, goats, digestibility, nutritive values, rumen and blood parameters.
\end{abstract}

\section{INTRODUCTION}

The available amount of green fodder through the summer season in Egypt is usually insufficient for animal feeding leading to increasing prices of 
diets. Therefore, attempts have been carried out to search for alternative nonconventional low price by-products, which could be used in animal feeding. Moreover, 21 million tons of agricultural crop residues are produced in Egypt annually (Deraz, 1996). However, only 4.0 to 4.3 million tons of these crop residues are used for feeding animals (Hathout and El-Nouby, 1990 and Khorshed, 2000).

Fibrous crop by-products or farm wastes are characterized by extensive lignification of the cellulose and the hemicellulose, and by low levels of protein, soluble carbohydrates and minerals (Van Hao and Ledin, 2001). One of these wastes is date palm and mid rib of date palm tree species (Phoenix dactylifera L.). It was generally known that date have a fundamental economic importance in many desert areas especially in south Sinai governorate in Egypt. Date fruit production yields several crop residues: date palm leaves (fronds), leaf petioles, racemes (without the dates) and the pedicels. Date palm leaves and their petioles can be used to feed livestock. They are used traditionally as a complementary feeding source by oasis dwellers Medjekal et al. (2011). A date palm tree can produce $13.5-20 \mathrm{~kg}$ of dry fronds annually Pascual et al. (2000).

The production of potato food products generates large amount of by-product material which has potential to be used as feed sources for ruminants. Approximately $35 \%$ of the total processed potato crop is discarded as a waste during processing. These wastes ferment rapidly and add to the pollution problem if not properly utilized.

All potato (Solanum tuberosum) products are good sources of energy for ruminants. Stanhope et al. (1980) reported that the digestible energy content of potato by-product was similar to that of barley when the byproduct was included in cattle diets 30 to $60 \%$ of dietary dry matter. Potatoes consist of $80 \%$ water and the water content of the peeling waste is usually more than $85 \%$. Process waste should be mixed to other feed so that the dry matter content of the mixture is adequate.

Sprouting grains for human consumption has been used for centuries in Asian countries to improve food value (Resh, 2001). Sprouts technique can be used for green fodder production of many forage crops for production of fresh forage from oats, barley, corn, wheat and other grains (RodriguezMuela et al., 2004).

Sprouts green fodder (SGF) produced is of a short growth period and does not require high-quality arable land, but only a small piece of land for production to take place (Mooney, 2005). Germination and sprouting activates enzymes change the starch, protein, and lipids of the grain into simpler forms, for example, starch changes to sugars. There are some arguments about the sprouting grains for convenience of green forage production in sprouting system to compensate the feed resources for animals (Rajendra et al., 1998 and Tudor et al., 2003). This technology may be especially important in the regions where forage production is limited (Mukhopad, 1994 and Bustos et al., 2000). Generally, the seeds are allowed to germinate and grow for about one to two weeks when a forage mat made up of the germinated seeds, their interwoven white roots, and the green shoots is obtained (Cuddeford, 1989). The whole product is then fed to the 
animals and the empty space in the chamber is used to germinate a new set of seeds (Mukhopad, 1994). It can be concluded that the biological and economical viability of production of sprouts technique will depend on sprouting systems, type and quality of the grain, particularly the germination rate, culturing conditions, management, and the local conditions that merits further investigation.

The objective of the present work is to study the effect of sprouts technique (planting) white corn seeds on mixture in different proportions from potatoes peel waste, (DPL) and date palm leaves, as media to produce green fodder in dried seasons to improve the palatability and nutritive value of green fodder that fed to goats and study their effects on digestibility, some rumen and blood parameters of goats.

\section{MATERIALS AND MEHODS}

The present work was carried out at South Sinai Research Station (Ras Suder City) which belongs to the Desert Research Center. Dried date palm leaves were collected and chopped into $2-3 \mathrm{~cm}$ and wet potato peel waste (PPW) was obtained from chipsy for food industries CO. S.A.E., $6^{\text {th }}$ October City. The waste was spread in thin layers on trays and left for sun drying and used as bedding media.

Production method for grains sprouts was tray method as described by Mohammadi et al. (2007) using about $10 \mathrm{~cm}$ thick layer of chopped dried date palm leaves (DPL) and potatoes peel waste (PPW) as a sprouting media. Cereal grains of local white corn (Zea Mays L.) were cleaned from debris and other foreign materials. Then the cleaned seeds were surface sterilized by soaking for 30 minutes in a $2 \%$ sodium hypochlorite solution to prevent the formation of mould. Planting trays and the growing cabinet also were cleaned and disinfected. The seeds were washed well from residues of bleach and re-soaked in tap water overnight (about 12 hours) before sowing. At the end of soaking period, soaked seeds were spread evenly on the top of date palm leaves (DPL) and potatoes peel waste (PPW) media. Germination period on the media surface lasted about 15 days to get shoot sprouts, shoot length was $20-23 \mathrm{~cm}$, seeding rate used in this experiment was about $10 \%$ density of roughage (DPL and PPW), planting trays were irrigated by tap water once a day early in the morning to provide enough water to keep the seeds/ seedlings moist.

The trays contained green fodders of tested media were removed from the chamber and the fresh fodder batches were representative samples ( $250 \mathrm{~g}$ each), in four replication, were oven-dried at $60^{\circ} \mathrm{C}$, ground to pass a 1 $\mathrm{mm}$ mesh screen sieve and stored for chemical analysis.

Twenty five desert male goats averaged eighteen months old with $22.76 \pm 1.29 \mathrm{~kg}$ live body weight) were divided randomly into five equal groups fed the following rations:

R1: alfalfa (Medicago sativa) hay (control).

R2: $75 \%$ potatoes peel waste (PPW) $+25 \%$ date palm leaves (DPL). 
R3: $50 \%$ potatoes peel waste (PPW) $+50 \%$ date palm leaves (DPL).

R4: $25 \%$ potatoes peel waste (PPW) $+75 \%$ date palm leaves (DPL).

R5: $100 \%$ date palm leaves (DPL).

Goats were used in a feeding trial lasted for fourty five days. The metabolism trials were conducted after the feeding trial to get the most nutritious sprouts green fodder (SGF) with concentrate feed mixture (CFM). Each goat group was housed in individual shaded pens and offered the dietary sprouts green fodder (SGF) in separate feeders daily plus the recommended amount of concentrate feed mixture (CFM) to cover $20 \%$ of their maintenance requirements according to of Kearl, (1982). concentrate feed mixture contained: 94.28 DM, 91.07 OM, 14.13 CP, 7.01 CF, 2.01 EE, 8.93 ash, 67.88 NFE, 17.39 GE, MJ/kg DM, 62.34 NDF, 9.57 ADF, 52.77 Hemicellulose, 37.66 C.CHO, 0.150 Sodium and 0.170 Potassium (as \% DM basis). Drinking water was available twice daily for animals. Combined water was calculated as Fresh-Dry diet $\mathrm{ml} / \mathrm{kgBW}$. Metabolic water was calculated from TDN intake a yield of $0.6 \mathrm{gm}$ water per gm TDN (Farid et al., 1986).

At the end of the experimental feeding, four animals from each group were randomly selected for the metabolism trial, fifteen day adaptation period followed by 5 days collection period. During the collection period, fecal and urine samples were collected daily ( $10 \%$ by weight of daily samples). Daily water intake was calculated and recorded. At the end of collection period of the metabolism trial, rumen, liquor was sampled by stomach tube at $0,3,6$ hours after feeding. Blood samples were taken from jugular vein after feeding.

Chemical composition of feeds residues, faeces and urine were determined according to the A.O.A.C. (1997). Fiber fraction (NDF and ADF) were determined according to Goering and Van Soest (1970). Rumen total volatile fatty acids (TVFA's) were tested (Warner, 1964) and ammonia nitrogen values were also evaluated (A.O.A.C. 1997). Sodium (Na) and potassium $(\mathrm{K})$ were determined in feed, refusal, feces, urine and drinking water by using the standard flame photometry (Jackson, 1958). Blood serum samples were assayed for total protein (Armstrong and Carr 1964), albumin (Doumas et al 1971). Globulin was obtained by subtracting the albumin values from the total proteins values. Serum creatinine (Henry1965) and urea (Patton and Crouch, 1977) were also determined all blood serum analysis was measured using Jenway spectrophotometer (UK) and using kits purchased from Human Company (Germany).

The data were subjected to the statistical analysis system according to SAS (1998). Differences in mean values between groups were compared by Duncan's multiple Range tests (1955).

\section{RESULTS AND DISCUSSION}

\section{Laboratory study:}

Data of Table 1 showed that chemical compositions of dried potatoes peel waste (PPW) were 13.89\% CP, $11.83 \% \mathrm{CF}, 1.21 \% \mathrm{EE}$ and $16.50 \mathrm{GE}$ $\mathrm{MJ} / \mathrm{kg} \mathrm{DM}$. These results were in agreement with those, obtained by 
Duynisveld and Charmley, (2002) and Boyles (2006), they recorded that CP in potato waste ranged between $4 \%$ to $14.3 \%$ and CF ranged between $1.6 \%$ to $17.5 \%$. Chemical compositions of dried date palm leaves (DPL) were $3.76 \% \mathrm{CP}, 33.15 \% \mathrm{CF}, 2.0 \% \mathrm{EE}$ and $15.70 \mathrm{GE} \mathrm{MJ} / \mathrm{kg} \mathrm{DM}$, which are in the same trend with those found by Chehma and Longo (2001), and Medjekal et al. (2011), they recorded that CP in dried date palm leaves (DPL) ranged between $3.9 \%$ to $5.6 \%$, CF ranged between $30.9 \%$ to $33.0 \%, 2.00 \%$ EE and 16.9 GE MJ/kg DM.

Results in Table 1 revealed that sprouting corn seeds on potatoes peel waste as a media had increased CP content from 13.89 to $15.17 \%$, EE from 1.21 to $2.39 \%$, C.CHO from 43.09 to 45.29 and ash from 13.07 to $22.93 \%$, and decreased OM content from 86.93 to $77.02 \%$, CF from 11.83 to $10.04 \%$, NDF from 56.91 to $54.71 \%$, and ADF from 28.15 to $20.37 \%$ as compared with unsprouted PPW. On the other hand, sprouting corn seeds on date palm leaves as a media had improved CP content from 3.75 to $7.52 \%$, EE from 2.20 to $2.22 \%$, C.CHO from 18.50 to 31.17 and ash content from 13.50 to $17.75 \%$ while decreased OM content from 89.88 to $82.25 \%$, CF from 33.15 to $31.99 \%$, NDF from 81.50 to $77.98 \%$, and ADF from 59.80 to $46.81 \%$ as compared with none sprouted DPL. Researcher in many ways demonstrated that CP increased in sprouting technique; Morgan et al. (1992) reported that CP content was increased from 10.8 (at day 4) to $14.9 \%$ (at day 8) in hydroponically barley fodder that were in accordance with our findings. Fazaeli et al. (2012) reported that CP content was increased from 14.32 (at day 6) to $20.04 \%$ (at day 8) in hydroponically barley fodder.

Table 1: Chemical composition and cell wall constituents of none sprouted and sprouted media (\% on DM basis)

\begin{tabular}{ccccccc}
\hline \multicolumn{7}{c}{ Treatments } \\
\hline Items & \multicolumn{7}{c}{ None Sprouted } & PPW & DPL & SCs & SPPW & SDPL \\
DM & 88.51 & 91.60 & 92.68 & 96.83 & 91.38 & 91.52 \\
OM & 98.53 & 86.93 & 89.88 & 93.36 & 77.02 & 82.25 \\
Ash & 1.47 & 13.07 & 13.50 & 6.64 & 22.98 & 17.75 \\
CP & 8.95 & 13.89 & 3.76 & 9.67 & 15.17 & 7.52 \\
CF & 1.92 & 11.83 & 33.15 & 7.13 & 10.04 & 31.99 \\
EE & 4.32 & 1.21 & 2.0 & 2.96 & 2.39 & 2.22 \\
NFE & 83.34 & 60.0 & 47.59 & 73.55 & 49.42 & 40.52 \\
NDF & 8.83 & 56.91 & 81.50 & 36.70 & 54.71 & 77.98 \\
ADF & 2.15 & 28.15 & 59.80 & 12.16 & 20.37 & 46.81 \\
Hemicellulose & 6.68 & 28.76 & 21.70 & 24.54 & 34.34 & 22.02 \\
C.CHO & 91.17 & 43.09 & 18.50 & 63.3 & 45.29 & 31.17 \\
GE MJ/kg DM & 18.90 & 16.50 & 15.70 & 17.80 & 15.10 & 17.34 \\
Sodium \% & 0.02 & 0.24 & 0.23 & 0.17 & 0.27 & 0.27 \\
Potassium \% & 0.46 & 0.13 & 0.15 & 0.08 & 0.14 & 0.17 \\
Calcium \% & 0.04 & 0.04 & 0.58 & 0.05 & 0.06 & 0.65 \\
Phosphorus \% & 0.24 & 0.22 & 0.09 & 0.25 & 0.24 & 0.1 \\
\hline
\end{tabular}

Cs: corn seed; (SCs): sprouted corn seed; (PPW): potatoes peel waste; (SPPW): sprouted potatoes peel waste; (DPL): date palm leaves; (SDPL): sprouted date palm leaves; DM: dry matter; OM: organic matter; CP: crude protein; CF: crude fiber; EE: ether extract; NFE: nitrogen free extract; NDF: natural detergent fiber; ADF: acid detergent fiber; C.CHO: converted carbohydrates = (100-NDF). GE: gross energy. 
Also, Al-Ajmi et al. (2009) found about $14 \%$ increase of CP in hydroponically barley green fodder. But, Snow et al. (2008) reported a higher $(16.13 \%)$ CP content, in hydroponically barley fodder and the CP contents could be affected by the cultivation conditions in hydroponic systems. Moreover, Lorenz (1980) stated that the sprouting of grains causes increased enzyme activity, a loss of total DM, an increase in total protein, a change in amino acid composition, a decrease in starch, increases in sugars, a slight increase in crude fat and crude fiber, and slightly higher amounts of certain vitamins and minerals. Most of the increases in nutrients are not true increases; they simply reflect the loss of DM, mainly in the form of carbohydrates, due to respiration during sprouting. As total carbohydrates decreases, the percentage of other nutrients increases.

\section{Chemical composition of the tested rations:}

The chemical composition of the different rations is shown in Table 2.There were wide variations between the chemical composition of the four sprouted mixtures fodder (R2, R3, R4 and R5) and alfalfa hay (R1). R2 contained the highest CP content $(15.17 \%)$ compared with other rations. On the other hand, lowest values of OM, CF, NFE and GE were recorded by R2. It was clear that as the portions of date palm leaves (DPL) in the ration increase the $\mathrm{CP}$, ash, sodium \% and potassium\% content decrease; however, $\mathrm{CF}$ and GE content increased. Fiber fractions in rations (R2, R3, R4 and R5) were increased by increasing the inclusion of DPL portion in the rations compared with R1. The improvement in sprouted mixtures may be attributed to increase the activity of sprouted corn seed hydrolytic enzymes which catabolized starch to soluble sugars for use in respiration and cell-wall synthesis during the germination and early stage of plant growing and lead to improvements in chemical composition of PPW and DPL. Similar results were obtained by Chavan and Kadam (1989).

Table 2: Chemical analysis and cell wall constituents of the tested rations (on DM basis)

\begin{tabular}{|c|c|c|c|c|c|}
\hline \multirow{2}{*}{ Composition } & \multicolumn{5}{|c|}{ Rations } \\
\hline & R1 & R2 & R3 & R4 & R5 \\
\hline Dry matter & 91.83 & 92.85 & 92.67 & 91.47 & 91.52 \\
\hline Organic matter & 84.18 & 58.03 & 68.11 & 73.80 & 82.25 \\
\hline Crude protein & 12.36 & 15.17 & 12.05 & 9.64 & 7.52 \\
\hline Crude fiber & 23.55 & 15.13 & 18.53 & 18.36 & 31.99 \\
\hline Ether extract & 2.20 & 1.36 & 1.58 & 1.18 & 2.22 \\
\hline Ash & 15.83 & 41.97 & 31.89 & 26.20 & 17.75 \\
\hline NFE & 46.06 & 26.37 & 35.95 & 44.62 & 40.52 \\
\hline NDF & 45.85 & 57.13 & 55.96 & 64.04 & 77.98 \\
\hline ADF & 30.75 & 38.09 & 37.34 & 42.77 & 46.81 \\
\hline Hemicellulose & 15.11 & 19.04 & 18.62 & 21.28 & 22.02 \\
\hline${ }^{*} \mathrm{C} . \mathrm{CHO}$ & 54.15 & 42.87 & 44.04 & 35.96 & 31.17 \\
\hline GE MJ/kg DM & 16.36 & 11.55 & 13.29 & 14.47 & 17.34 \\
\hline Sodium \% & 0.43 & 0.263 & 0.230 & 0.210 & 0.168 \\
\hline Potassium \% & 0.605 & 0.213 & 0.202 & 0.184 & 0.150 \\
\hline
\end{tabular}

Gross energy: $\mathrm{MJ} / \mathrm{kg} \mathrm{DM}=\left(\mathrm{CP}{ }^{*} 0.0226+\mathrm{EE}^{\star}{ }^{\star} 0.0407+\mathrm{CF}^{\star} 0.0192+\mathrm{NFE}{ }^{\star} 0.0177\right)$ (MAFF 1975), NFE: nitrogen free extract, NDF: natural detergent fiber, ADF: acid detergent fiber,
(C.CHO): converted carbohydrates calculated (NDF-100), GE: gross energy, R1: alfalfa (control), R2: $75 \%$ potatoes peel waste (PPW) $+25 \%$ date palm leaves (DPL), R3: $50 \%$ potatoes peel waste (PPW) $+50 \%$ date palm leaves (DPL), R4: $25 \%$ potatoes peel waste (PPW) $+75 \%$ date palm leaves (DPL) R5: $100 \%$ date palm leaves (DPL). 
By enhancing the time of sprouting, the higher organic matter, particularly starch consumed to support the metabolism and energy requirement of the growing (Chavan and Kadam, 1989), therefore resulted in a lower OM and higher ash in sprouted grain. According to Kent-Jones and Amos (1967), after 6 days of growing, starch accounted for $53-67 \%$ of the dry weight of barley seed, so any decrease in the amount of starch would cause a corresponding decrease in OM, NFE and DM as well. In addition, the increase in EE could be due to the production of chlorophyll associated with plant growth (Mayer and Poljakoff-Mayber 1975).

\section{Feed intake and digestion coefficient}

Feed intake, digestion coefficients and nutritive values are presented in Table 3. Goats fed on alfalfa hay (R1) recorded the highest DMI. The results are also in conformity with Fazaeli et al. (2011), who reported that the animals that had received the control diet (barley green) had higher ( $\mathrm{P} \leq 0.05)$ dry matter intake than those fed sprouted barley green fodder. Differences in DMl between treatments (R2, R3, R4 and R5) were not significant.

It is clearly indicated that sprouting corn seeds on date palm leaves fed animals (R5) recorded the highest $(P \leq 0.05)$ digestibility coefficients of $\mathrm{DM}, \mathrm{OM}, \mathrm{CF}, \mathrm{EE}, \mathrm{NDF}$ and $\mathrm{C} . \mathrm{CHO}$ with lowest value of $\mathrm{CP}$ digestibility coefficient. Highest digestibility coefficients of $\mathrm{CP}$ was recorded by animals fed R2 (81.72\%) with no differences between R1, R2 and R3. This may be attributed to fresh grains sprouts have been reported to have highly soluble protein and amino acids in response to the enzymatic transformations during early plant growth (Chung et al., 1989 and Dikshit and Ghadle, 2003). Sprouting corn seeds on our four studied mixtures had the highest $(P \leq 0.05)$ values in digestibility coefficients of EE and $\mathrm{C}$.CHO compared with animals fed R1. On the other hand, there were no significant differences among the five rations in their digestibility coefficients of ADF and hemicellulose. This may be attributed to increase in the bioactive catalysts which assist in the digestion and metabolism of feeds and the release of energy. Similar results were reported by Shipard (2005) who found that feeding sprouted grains provided animals with living feed which has a rich supply of enzymes which results in all nutritional components being highly digestible and extremely nutritious.

Generally, digestibility coefficients of all nutrients were significantly $(P \leq 0.05)$ higher in sprouted corn seeds on our four studied mixtures. Similar trends were observed by Fayed (2011) who found that the digestibility coefficients of all nutrients for sprouted barley on rice straw and Tamarix were higher than that of untreated.

When the nutritive values expressed as TDN $\mathrm{g} / \mathrm{kg} \mathrm{B.W}$ and DCP $\mathrm{g} / \mathrm{kg}$ B.W or DCP\%, a significant differences $(P \leq 0.05)$ was detected among groups. It was higher in animals fed R1 and R5 followed by R4, R3 and the lowest R2.

Highest DCP g/kg B.W (5.31) and DCP\% (11.89) were recorded by $\mathrm{R} 2$ compared with other studied rations. $\mathrm{R} 3$ and $\mathrm{R} 1$ were considered as fair values of DCP\% (being 10.42 and $10.09 \%$, respectively). On the other hand, lowest values were recorded by R5; these results may be attributed to low $\mathrm{CP}$ 
digestibility coefficients of animals fed R5. Similar results are in the same trend with those found by (Fayed, 2011 and Helal, 2012) they recorded that nutritive values are improved when sprouted barley on dried Acacia saligna, Tamarix mannifera or rice straw as a media were higher than those for untreated roughages.

Table 3: Average daily feed intake, digestion coefficient and nutritive value of goats fed the sprouted fodder.

\begin{tabular}{|c|c|c|c|c|c|c|}
\hline \multirow[t]{2}{*}{ Items } & \multicolumn{5}{|c|}{ Sprouted fodder } & \multirow[b]{2}{*}{$\pm \mathrm{SE}$} \\
\hline & R1 & R2 & R3 & R4 & R5 & \\
\hline No. of animals & 4 & 4 & 4 & 4 & 4 & \\
\hline Live body weight & 22.83 & 22.16 & 22.76 & 22.16 & 22.66 & 1.22 \\
\hline \multicolumn{7}{|l|}{ Dry matter intake $\mathrm{g} / \mathrm{kg} \mathrm{BW}$} \\
\hline Concentrate feed Mixture & $7.19^{a}$ & $6.38^{b}$ & $6.34^{b}$ & $6.34^{\mathrm{b}}$ & $6.35^{b}$ & 0.09 \\
\hline Sprouted mixture fodder & 24.00 & 23.37 & 21.97 & 22.15 & 23.64 & 3.38 \\
\hline Total feed intake & 31.19 & 29.99 & 28.32 & 28.50 & 29.75 & 3.43 \\
\hline \multicolumn{7}{|l|}{ Digestion coefficients \% } \\
\hline DM & $73.69^{b}$ & $75.30^{a b}$ & $76.67^{a b}$ & 76.89 ab & $77.48^{a}$ & 1.07 \\
\hline OM & $75.94^{b}$ & $72.57^{\mathrm{c}}$ & $76.19^{b}$ & $74.91^{b c}$ & $79.38^{a}$ & 0.83 \\
\hline $\mathrm{CP}$ & $81.63^{a}$ & $81.72^{a}$ & $79.53 \mathrm{ab}$ & $74.78 \mathrm{bc}$ & $72.73^{c}$ & 1.53 \\
\hline CF & $64.32^{d}$ & $68.55^{\mathrm{c}}$ & $73.14^{b}$ & $74.09^{b}$ & $82.86^{a}$ & 0.95 \\
\hline EE & $45.48^{b}$ & $85.79^{a}$ & $84.76^{a}$ & $80.11^{a}$ & $85.00^{a}$ & 1.99 \\
\hline NFE & $81.80^{\mathrm{a}}$ & $70.39^{c}$ & $76.13^{b}$ & $75.62^{b}$ & $77.91^{b}$ & 0.98 \\
\hline NDF & $70.03^{b}$ & $71.31^{b}$ & $72.40^{b}$ & $74.02^{b}$ & $78.61^{a}$ & 1.31 \\
\hline ADF & 72.71 & 74.96 & 76.37 & 76.48 & 75.14 & 1.86 \\
\hline Hemicellulose & 64.61 & 63.57 & 64.85 & 69.39 & 78.38 & 2.30 \\
\hline C.CHO & $76.78^{\mathrm{b}}$ & $82.49^{a}$ & $82.68^{a}$ & $79.23^{a b}$ & $79.14^{a b}$ & 1.57 \\
\hline \multicolumn{7}{|l|}{ Nutritive values } \\
\hline \multicolumn{7}{|l|}{ Total digestible nutrient intake } \\
\hline $\mathrm{g} / \mathrm{kg} \mathrm{BW}$ & $37.01^{\mathrm{a}}$ & $22.00^{b}$ & $24.95^{b}$ & $27.15^{b}$ & $29.99^{a b}$ & 2.63 \\
\hline$\%$ of intake & $65.17^{a b}$ & $49.27^{c}$ & $57.84^{b}$ & $59.68^{b}$ & $68.95^{\mathrm{a}}$ & 2.61 \\
\hline \multicolumn{7}{|l|}{ Digestible crude protein intake } \\
\hline $\mathrm{g} / \mathrm{kg} \mathrm{BW}$ & $5.19^{\mathrm{a}}$ & $5.31^{\mathrm{a}}$ & $4.55^{\mathrm{ab}}$ & $3.52^{\mathrm{ab}}$ & $2.77^{\mathrm{b}}$ & 0.63 \\
\hline$\%$ of intake & $10.09^{b}$ & $11.89^{a}$ & $10.42^{b}$ & $7.69^{\mathrm{c}}$ & $6.30^{d}$ & 0.41 \\
\hline
\end{tabular}

R1: alfalfa (control), R2: $75 \%$ potatoes peel waste (PPW) $+25 \%$ date palm leaves (DPL) R3: $50 \%$ potatoes peel waste (PPW) $+50 \%$ date palm leaves (DPL), R4: $25 \%$ potatoes peel waste (PPW) $+75 \%$ date palm leaves (DPL) R5: $100 \%$ date palm leaves (DPL). a, b $c$ :means with different superscripts in the same row differ significantly $(p \leq 0.05)$, otherwise no differences were detected.

\section{Nitrogen utilization and minerals balance:}

Data of $\mathrm{N}$-balance recorded for the five experimental rations are reported in Table 4. Nitrogen utilization ( $\mathrm{g} / \mathrm{head} / \mathrm{day}$ ) was affected significantly $(P \leq 0.05)$ by sprouting corn seeds on the four studied mixtures.

Nitrogen intake $(\mathrm{NI})$ was significantly $(\mathrm{P} \leq 0.05)$ higher in $\mathrm{R} 1(28.16)$ followed by R2 (22.93) while the lowest was recorded for R5 (13.60). The higher nitrogen intake may due to high content of crude protein in alfalfa R1 and sprouted mixture R2 (Table, 2). Goats fed R1 and R2 had highest $(P \leq 0.05)$ fecal and urinary nitrogen compared with other groups. While animals fed R2 and R3 had significant $(P \leq 0.05)$ higher amounts of nitrogen retention compared with other groups, while not significantly different between the treatments in nitrogen retention as a percent of total nitrogen intake ( $\mathrm{NR} \%$ of $\mathrm{NI})$. This finding may be related to higher improvement in $\mathrm{CP}$ intake and its digestibility in sprouted mixtures compared with other 
experimental forages. These results are in similar trend with those found by (Fayed 2011 and Helal 2012).

Data on $\mathrm{Na}$ and $\mathrm{K}$ utilization revealed that $\mathrm{Na}$ intake, excretion and balance $(\mathrm{g} / \mathrm{kg} \mathrm{BW}$ ) were varied significantly $(P \leq 0.05)$ among the experimental groups. The highest $(P \leq 0.05)$ values of $\mathrm{Na}$ and $\mathrm{K}$ intake and excretion were for R1. However, differences between the sprouted mixtures R2, R3, R4 and R5 were not significan. After sprouting and the depletion of nutrients from original seeds, roots plants that absorb nutrients from the media for the continued growth and life, which leads to reduced organic matter of the media with, increase the mineral, Also Morgan et al. (1992) found that ash content of sprouts increased from 2.1 in original seed (barley) to 5.3 at 8 day with increasing trace minerals.

Table 4: Nitrogen utilization and minerals balance for goats fed the sprouted fodder.

\begin{tabular}{|c|c|c|c|c|c|c|}
\hline \multirow[b]{2}{*}{ Items } & \multicolumn{6}{|c|}{ Sprouted fodder } \\
\hline & R1 & R2 & R3 & R4 & R5 & $\pm \mathrm{SE}$ \\
\hline \multicolumn{7}{|c|}{ Nitrogen utilization (g/head/day) } \\
\hline Nitrogen intake (NI) & $28.16^{a}$ & $22.93 a b$ & $18.59^{b c}$ & $15.47^{c}$ & $13.60^{c}$ & 2.18 \\
\hline Fecal nitrogen (FN) & $5.01^{a}$ & $4.33^{a b}$ & $3.81^{a b}$ & $3.92^{a b}$ & $3.70^{b}$ & 0.37 \\
\hline urinary nitrogen (UN) & $21.16^{a}$ & $12.60^{b}$ & $9.40^{b}$ & $9.77^{b}$ & $8.10^{b}$ & 2.07 \\
\hline Total nitrogen excretion (TNE) & $26.18^{a}$ & $16.93^{b}$ & $13.22^{b}$ & $13.69^{b}$ & $11.80^{b}$ & 2.27 \\
\hline Nitrogen retention (NR) & $3.36^{a b}$ & $5.99^{a}$ & $5.37^{a}$ & $1.78^{b}$ & $1.79^{b}$ & 0.88 \\
\hline NR \% of nitrogen intake & 14.90 & 26.34 & 28.53 & 11.52 & 13.26 & 2.66 \\
\hline Fecal N\% of nitrogen intake & $18.36^{c}$ & $18.88^{c}$ & $20.46^{b c}$ & $25.21^{a b}$ & $27.27^{a}$ & 1.57 \\
\hline Urinary $\mathrm{N} \%$ of nitrogen intake & $79.58^{a}$ & $54.77^{b}$ & $58.53^{b}$ & $63.26^{b}$ & $59.47^{b}$ & 2.86 \\
\hline Digested nitrogen (DN) & $23.15^{a}$ & $18.59^{a b}$ & $14.78^{b c}$ & $11.55^{c}$ & $9.89^{c}$ & 1.94 \\
\hline DN \% of nitrogen intake & $81.63^{a}$ & $81.12^{a}$ & $79.53^{a b}$ & $74.78^{b c}$ & $72.73^{c}$ & 1.57 \\
\hline \multicolumn{7}{|l|}{$\begin{array}{c}\text { Minerals Balance }(\mathrm{g} / \mathrm{kg} \mathrm{BW}) \\
\text { Sodium }\end{array}$} \\
\hline Sodium Intake & $0.256^{a}$ & $0.103^{b}$ & $0.093^{b}$ & $0.090^{b}$ & $0.076^{b}$ & 0.009 \\
\hline Feces Sodium excretion & 0.023 & 0.013 & 0.013 & 0.016 & 0.013 & 0.003 \\
\hline Urine Sodium excretion & $0.226^{a}$ & $0.060^{b}$ & $0.056^{b}$ & $0.053^{b}$ & $0.043^{b}$ & 0.005 \\
\hline Total Sodium excretion & $0.243^{a}$ & $0.073^{b}$ & $0.073^{b}$ & $0.073^{b}$ & $0.060^{b}$ & 0.006 \\
\hline Sodium Balance & 0.013 & 0.030 & 0.023 & 0.016 & 0.013 & 0.009 \\
\hline \multicolumn{7}{|l|}{ Potassium } \\
\hline Potassium Intake & $0.356^{a}$ & $0.090^{b}$ & $0.086^{b}$ & $0.080^{b}$ & $0.066^{b}$ & 0.009 \\
\hline Feces Potassium excretion & $0.020^{\mathrm{a}}$ & $0.010^{\mathrm{b}}$ & $0.010^{\mathrm{b}}$ & $0.013^{b}$ & $0.010^{\mathrm{b}}$ & 0.001 \\
\hline Urine Potassium excretion & $0.316^{a}$ & $0.033^{\mathrm{b}}$ & $0.040^{\mathrm{b}}$ & $0.046^{\mathrm{b}}$ & $0.033^{\mathrm{b}}$ & 0.012 \\
\hline Total Potassium excretion & $0.333^{a}$ & $0.040^{\mathrm{b}}$ & $0.050^{\mathrm{b}}$ & $0.056^{\mathrm{b}}$ & $0.040^{\mathrm{b}}$ & 0.014 \\
\hline Potassium Balance & 0.023 & 0.043 & 0.036 & 0.023 & 0.026 & 0.011 \\
\hline
\end{tabular}

R1: alfalfa (control), R2: $75 \%$ potatoes peel waste (PPW) $+25 \%$ date palm leaves (DPL) R3: $50 \%$ potatoes peel waste (PPW) $+50 \%$ date palm leaves (DPL), R4: $25 \%$ potatoes peel waste (PPW) + 75\% date palm leaves (DPL) R5: 100\% date palm leaves (DPL) a, b, c :means with different superscripts in the same row differ significantly $(p \leq 0.05)$, otherwise no differences were detected.

\section{Water utilization:}

Data of Table 5 showed that water intake (in terms of drinking, combined and metabolic water) were varied $(P \leq 0.05)$ significantly among animal groups. Water intakes was $(P \leq 0.05)$ higher in goats fed $R 1$ compared with the four sprouted groups; however, goats in R2, R3, R4 and R5 tended to consume comparable amounts of water without significant differences. The 
highest amount of total water consumption was recorded (193.02 ml/kg/BW) for goats fed R1 compared with other groups. May be due to increasing of dry matter intake (Table 3) and high content of sodium and potassium\% (Table 2) in alfalfa fed to goats in R1. While there were no significant differences in total consumption of water among sprouted groups R2, R3, R4 and R5. On the other hand, goats fed R1 had highest significant total water excreted (106.68). These findings are in agreement with Eid (2003) and Allam et al. (2006) on animals fed similar dietary rations. They reported that feeding animals salt tolerant fodders of high ash content led to push animals to increase excretion of urine. Water balance was higher $(P \leq 0.05)$ in $R 1$ with no differences among the four sprouted groups which mainly attributed to the pattern of water consumption and total water intake (Eid, 2003 and Allam et al., 2006).

Table 5: Water balance $(\mathrm{ml} / \mathrm{kg} / \mathrm{BW})$ of goats fed the sprouted fodders

\begin{tabular}{|c|c|c|c|c|c|c|}
\hline \multirow{2}{*}{ Item } & \multicolumn{5}{|c|}{ Sprouted fodder } & \multirow{2}{*}{ \pm SE } \\
\hline & R1 & R2 & R3 & R4 & R5 & \\
\hline Drinking water & $114.84^{a}$ & $22.38^{b}$ & $21.70^{b}$ & $26.26^{b}$ & $23.91^{b}$ & 7.57 \\
\hline Combined water & $54.94^{\mathrm{a}}$ & $9.79^{b}$ & $4.77^{\mathrm{b}}$ & $7.39^{b c}$ & 4.82 & 1.23 \\
\hline Metabolic water & $23.23^{a}$ & $13.20^{b}$ & $14.97^{b}$ & $16.29^{b}$ & $17.99^{b}$ & 1.48 \\
\hline Total water intake & $193.02^{a}$ & $45.38^{b}$ & $41.44^{b}$ & $49.95^{b}$ & $46.73^{b}$ & 9.08 \\
\hline Fecal water & $20.74^{a}$ & $3.08^{b}$ & $2.23^{b}$ & $2.43^{b}$ & $1.57^{b}$ & 0.74 \\
\hline$\%$ of Intake & $18.99^{a}$ & $14.63^{a b}$ & $10.70^{a b}$ & $9.19^{a b}$ & $6.41^{\mathrm{b}}$ & 3.14 \\
\hline Urinary water & $85.94^{a}$ & $18.06^{b}$ & $17.63^{b}$ & $20.25^{b}$ & $17.36^{b}$ & 4.72 \\
\hline$\%$ of Intake & 75.67 & 81.68 & 80.60 & 78.92 & 71.25 & 6.66 \\
\hline Total water excreted & $106.68^{a}$ & $21.14^{b}$ & $19.86^{b}$ & $22.69^{b}$ & $18.93^{b}$ & 4.66 \\
\hline$\%$ of Intake & 94.66 & 96.31 & 91.30 & 88.12 & 77.66 & 8.44 \\
\hline Water balance & $86.33^{a}$ & $24.25^{b}$ & $21.58^{b}$ & $27.93^{b}$ & $27.79^{b}$ & 5.10 \\
\hline$\%$ of Intake & $76.21^{\mathrm{b}}$ & $105.69 \mathrm{ab}$ & $99.70^{a b}$ & $102.42^{a b}$ & $119.25^{a}$ & 10.57 \\
\hline
\end{tabular}

R1: Alfalfa (control), R2: 75\% potatoes peel waste (PPW) + 25\% date palm leaves (DPL), R3: $50 \%$ potatoes peel waste (PPW) $+50 \%$ date palm leaves (DPL), $\mathbf{R} 4: 25 \%$ potatoes peel waste (PPW) + 75\% date palm leaves (DPL) $\quad$ R5: $100 \%$ date palm leaves (DPL). $a, b$, C :Means with different superscripts in the same row differ significantly $(P \leq 0.05)$, otherwise no differences were detected.

\section{Rumen parameters:}

Data of rumen total volatile fatty acids (TVFA,s) and ammonianitrogen are presented in Table 6. Rumen total volatile fatty acids (TVFA,s) revealed that sprouted corn grains increased TVFA,S concentrations in the rumen, which increased after feeding and reaches its peak after $3 \mathrm{hr}$. post feeding. There was a significant $(P \leq 0.05)$ increase in overall total volatile fatty acids (TVFA,s) concentrations; where animals in R4 showed the greatest values being $(10.20 \mathrm{meq} / 100 \mathrm{ml})$ followed by those in $\mathrm{R} 1$ (9.50), R3 (9.09), R5 (8.83) and R2 (8.79). It might be a reflection to rich energy and organic matter of fodder fed to small ruminants that provided higher concentrations of rumen metabolites which naturally improved rumen function and digestibility (Bonsi et al. 1995).

The increase in TVFA,S concentration with sprouted barley may be due to that sprouts provide a good supply of vitamins, enzymes which serve as bioactive catalysts to assist in metabolism of feed and the release of energy (Shipard ,2005, Fayed, 2011 and Helal, 2012). 
It was clear that goats in R2 recorded the highest significant overall ammonia-nitrogen value $(34.77 \mathrm{mg} / 100 \mathrm{ml})$ compared to the other experimental groups. This is may be due to high content of CP and CP intake in R2 (15.17\%, Table 2) fed to animals in this group (Norton, 2003). Other researchers reported an increase in rumen ammonia $\mathrm{N}$ with increase in $\mathrm{CP}$ supplementation (Bohnert et al., 2002; and Salisbury et al., 2004).

Table (6): Ammonia-nitrogen and total volatile fatty acids of goats fed the experimental fodder

\begin{tabular}{|c|c|c|c|c|c|c|c|}
\hline \multirow{2}{*}{ Criteria } & \multicolumn{7}{|c|}{ Sprouted fodder } \\
\hline & Time & R1 & R2 & R3 & $\mathrm{R} 4$ & R5 & overall mean \\
\hline \multicolumn{8}{|l|}{ TVFA,S } \\
\hline & 0 & $6.22 \pm 0.70 \mathrm{ab}$ & $4.44 \pm 0.70^{b}$ & $5.08 \pm 0.66 \mathrm{ab}$ & $6.88 \pm 0.70^{a}$ & $6.99 \pm 0.41^{a}$ & $5.92 \pm 0.43^{c}$ \\
\hline & 3 & $11.77 \pm 1.07$ & $11.51 \pm 1.07$ & $11.80 \pm 1.07$ & $12.55 \pm 1.07$ & $13.29 \pm 1.07$ & $12.18 \pm 0.43^{a}$ \\
\hline & 6 & $10.52 \pm 1.03$ & $10.41 \pm 1.03$ & $10.40 \pm 1.03$ & $11.16 \pm 1.03$ & $12.08 \pm 1.03$ & $9.74 \pm 0.43^{b}$ \\
\hline \multirow{4}{*}{$\begin{array}{l}\text { overall m. } \\
{ }^{*} \mathrm{NH}-\mathrm{N}\end{array}$} & & $9.50 \pm 0.56^{b}$ & $8.79 \pm 0.56^{b}$ & $9.09 \pm 0.56^{b}$ & $10.20 \pm 0.56^{a}$ & $8.83 \pm 0.56^{b}$ & \\
\hline & 0 & $22.13 \pm 1.08^{b}$ & $29.75 \pm 1.08^{a}$ & $22.76 \pm 1.07^{b}$ & $22.63 \pm 0.89^{b}$ & $20.19 \pm 0.72^{b}$ & $23.49 \pm 0.34^{c}$ \\
\hline & 3 & $39.49 \pm 0.59 a$ & $39.71 \pm 0.59^{a}$ & $37.82 \pm 0.59 \mathrm{ab}$ & $36.88 \pm 0.59^{b}$ & $27.96 \pm 0.59^{c}$ & $36.37 \pm 0.34^{a}$ \\
\hline & 6 & $34.48 \pm 0.66^{a}$ & $34.86 \pm 0.66^{a}$ & $33.73 \pm 0.66^{a b}$ & $31.70 \pm 0.66^{b}$ & $22.23 \pm 0.66^{c}$ & $31.40 \pm 0.34^{b}$ \\
\hline overall $\mathrm{m}$. & & $32.03 \pm 0.45^{b}$ & $34.77 \pm 0.45^{a}$ & $31.44 \pm 0.45^{b c}$ & $30.40 \pm 0.45^{c}$ & $23.46 \pm 0.45^{d}$ & \\
\hline
\end{tabular}
TVFA,s: Total volatile acids meq/100ml: (NH3-N); Ammonia nitrogen $\mathrm{mg} / 100 \mathrm{ml}$.

R1: alfalfa (control), R2: $75 \%$ potatoes peel waste (PPW) $+25 \%$ date palm leaves (DPL), R3: $50 \%$ potatoes peel waste (PPW) $+50 \%$ date palm leaves (DPL), $R 4: 25 \%$ potatoes peel waste (PPW) + 75\% date palm leaves (DPL) $R 5: 100 \%$ date palm leaves (DPL) $a, b, c$ :means with different superscripts in the same row differ significantly $(P \leq 0.05)$, otherwise no differences were detected.

\section{Blood parameters:}

Data of serum constituents of the studied goats as affected by sprouting corn seeds on the studied mixtures are given in Table 7 . Serum urea-N did not affect significantly. Creatinine $(\mathrm{mg} / \mathrm{dl})$, total protein $(\mathrm{g} / \mathrm{dl})$, albumin $(\mathrm{g} / \mathrm{dl})$, globulin $(\mathrm{g} / \mathrm{dl})$, ALT $(\mathrm{U} / \mathrm{L})$ and AST $(\mathrm{U} / \mathrm{L})$ were significantly elevated $(P \leq 0.05)$ by treatments. Goats fed R1 increased $(P \leq 0.05)$ serum total proteins, albumin, globulin, ALT and AST. The high level of globulin of sprouted barely treatments may indicate good developed immunity status (Ibrahim et al., 2001). This is in accordance with those reported by Kumar et al. (1980) who found a positive correlation between dietary protein and plasma protein concentration. Also, means of serum creatinin increased significantly $(P \leq 0.05)$ with $R 3$. This was probably due to the high level of $C P$ content in R3. The lowest value of serum urea and creatinin were recorded by R5. These results are in harmony with those reported by Fayed (2011). Additionally, Elisabetta et al. (2009) induced that integration with hydroponically germinating oat in partial substitution of the complete feed does not modify biochemical and hematological parameters and seems to produce an improvement in animal.

Serum minerals revealed that goats fed $R 1$ had highest $(P \leq 0.05)$ values of calcium and potassium (mg/dl) being 9.93 and 4.52; while, R1 and $\mathrm{R} 2 \mathrm{had}$ fair values of sodium and phosphorus $(\mathrm{mg} / \mathrm{dl})$ as compared with other groups (Table7). 
Helal, H. G. and Mona M. Hassan

Table 7: Blood metabolites changes of sheep fed the experimental diet

\begin{tabular}{|c|c|c|c|c|c|c|}
\hline \multirow{2}{*}{ Item } & \multicolumn{5}{|c|}{ Rations } & \multirow{2}{*}{$\pm \mathrm{SE}$} \\
\hline & R1 & R2 & R3 & R4 & R5 & \\
\hline Urea (mg/dl) & 37.25 & 37.55 & 37.00 & 36.23 & 35.88 & 0.66 \\
\hline Creatinine $(\mathrm{mg} / \mathrm{dl})$ & $1.54^{\mathrm{b}}$ & $1.53^{\mathrm{b}}$ & $1.55^{\mathrm{a}}$ & $1.41^{\mathrm{b}}$ & $1.34^{\mathrm{b}}$ & 0.03 \\
\hline Total protein $(\mathrm{g} / \mathrm{dl})$ & $6.63^{\mathrm{a}}$ & $6.06^{b}$ & $5.93^{b c}$ & $5.84^{c}$ & $5.68^{d}$ & 0.04 \\
\hline Albumin $(\mathrm{g} / \mathrm{dl})$ & $2.71^{\mathrm{a}}$ & $2.50^{\mathrm{b}}$ & $2.46^{b c}$ & $2.39^{\mathrm{cd}}$ & $2.36^{d}$ & 0.02 \\
\hline Globulin ( $\mathrm{g} / \mathrm{dl})$ & $4.02^{a}$ & $3.82^{b}$ & $3.56^{c}$ & $3.46^{d c}$ & $3.31^{d}$ & 0.05 \\
\hline $\operatorname{ALT}(\mathrm{U} / \mathrm{L})$ & $13.25^{\mathrm{a}}$ & $10.20^{b}$ & $9.73^{b}$ & $8.74^{c}$ & $7.36^{d}$ & 0.28 \\
\hline AST (U/L) & $20.25^{a}$ & $18.33^{b}$ & $21.12^{a}$ & $21.36^{\mathrm{a}}$ & $21.14^{\mathrm{a}}$ & 0.38 \\
\hline Calcium (mg/dl) & $9.93^{a}$ & $9.23^{b}$ & $8.36^{c}$ & $7.87^{d}$ & $7.83^{d}$ & 0.10 \\
\hline Phosphorus (mg/dl) & $5.85^{\mathrm{ab}}$ & $6.01^{a}$ & $5.80^{\mathrm{b}}$ & $5.54^{\mathrm{c}}$ & $5.42^{c}$ & 0.05 \\
\hline Sodium (mg/dl) & $150.83^{a}$ & $147.33^{a}$ & $137.66^{b}$ & $133.00^{b c}$ & $130.00^{c}$ & 2.02 \\
\hline Potassium (mg/dl) & $4.52^{\mathrm{a}}$ & $4.00^{\mathrm{b}}$ & $4.06^{\mathrm{b}}$ & $4.08^{b}$ & $4.07^{\mathrm{b}}$ & 0.06 \\
\hline
\end{tabular}

R1: alfalfa (control), R2: $75 \%$ potatoes peel waste (PPW) $+25 \%$ date palm leaves (DPL) R3: $50 \%$ potatoes peel waste (PPW) $+50 \%$ date palm leaves (DPL), R4: $25 \%$ potatoes peel waste (PPW) $+75 \%$ date palm leaves (DPL) $R 5: 100 \%$ date palm leaves (DPL). a, b, c, d means with different superscripts in the same row differ significantly $(P \leq 0.05)$, otherwise no differences were detected.

\section{CONCLUSION}

It could be concluded that we can produce green fodder especially in dry season by sprouting white corn seeds on roughages like date palm leaves (Phoenix dactylifera L.) and potatoes peels waste (Solanum tuberosum) as a media mixture (with percent 50\% PPW and 50\% DPL) high nutritive value for the animals and environment-friendly as well as reduce the cost of feeding by utilizing dried desert and agriculture by-products with simple methodology using crop sprouts and employ to produce forage feed instead of causing pollution.

\section{REFERENCES}

Al-Ajmi, A., A. Salih, I. Kadhim and Y. Othman (2009). Yield and water use efficiency of barley fodder produced under hydroponic system in GCC countries using tertiary treated sewage effluents. Journal of Phytology, 1(5): 342-348.

Allam, Sabbah M.; Youssef, K. M.; Ali, M. A. and Abo Bakr, S. Y. (2006). Using somefodder shrubs and industrial by-products in different forms for feeding Goats in sinai. J Agric. Sci. Mansoura Univ., 31: 1371-1385.

A.O. A. C. (1997): Official Methods of Analysis. $16^{\text {th }}$ Ed. Assoc. Office. Anal. Chem., Arlington, VA.

Armstrong, W.D. and C.W. Carr (1964). Physiological chemistry. Laborator Direction, 3 rd ed., P. 75, Burges bublishing Co. Minneapolis, Minnestota. Artificially Grown Barley Fodder by Sheep. Indian J. Small Rumen, 4(2): 63-68.

Bohnert, D.W., C.S. Schauer, S.J. Falck and T. DelCurto (2002). Influence of rumen protein degradability and supplementation frequency on steers consuming low-quality forage: I. Ruminal fermentation characteristics. J. Anim. Sci., 80: 2978-2988. 
Bonsi, M. L. K., P. O. Osuji and A. K. Thuah (1995). Effect of supplementing tef straw with different level of Leucaena or sasbania on the degradability of tef straw, sesbania, leucaena, tagaste and vernonia and certain rumen and blood metabolities in Ethopianmenz sheep. Anim. Feed Sci Technol 52; 101-129.

Boyles, S. (2006). Feeding potato processing wastes and culls to cattle. OSU Extension Beef Specialist. http:// beef, osu.edu/ library/ potato. Html.

Bustos, C. D. E., E. L. Gonzalez., B. A. Aguilera and G. J. A. Esptnoza (2000). Forraje Hidropónico, Una Alternativa para la Supplementation Caprina En el Semi desire to Queretano. XXXVIII. Reunión Nacional de Investigación Pecuaria. Puebla, México, 383 PP.

Chavan, J. and S.S. Kadam (1989). "Nutritional improvement of cereals by sprouting." Critical Reviews in Food Science and Nutrition, 28 (5): 401437.

Chehma, A. and Longo, H. F., (2001). Valorisation des sous-produits du palmier dattier en vue de leur utilisation en alimentation du bétail. Rev. Energ. Ren.

Production et.Valorisation - Biomasse: 59-64.

Chung, T., Nwokolo, E.N. and J.S. Sim (1989). Compositional and digestibility changes in sprouted barley and canola seeds. Plant Foods for Human Nutrition, 39:267-278.

Cuddeford, D. (1989). Hydroponic Grass. In Practice, 11(5): 211-214.

Deraz, T.A. (1996). The production of microbial protein from some agricultural wastes and its utilization in ruminant. Ph.D thesis Faculty of Agriculture, Ain Shams University.

Dikshit, M. and Ghadle, (2003). Effect of sprouting on nutrients, anti- nutrients and in vitro digestibility of MACS.13 soybean variety. Plant Food Hum.Natr, 58: 1-11.

Doumas, B., Wabson, W. and Biggs H. (1971). Albumin standards and measurement of serum with bromocresol green. Clin, Chem., Acta.

Duncan, D.B., (1955). Multiple ranges and multiple. F. tests Biometrics. 11, 142.

Duynisveld, J.L. and E. Charmely (2002). Beef cattle can successfully be fed $80 \%$ potato waste in the finishing diet. Www.asas. Org / abstracts / 2002 / Jnabs 18.pdf.

Eid, E. Y. A. (2003). Feed utilization and performance of animal fed the natural and cultivated fodder shrubs in Sinai. Ph D. Thesis, Fac. of Agric. Cairo univ. Egypt.

Elisabetta, M., R. Marco., M. Fabrizio., R. Giuseppe., M. Giuseppe and Z. Antonia (2009). Improvement of sheep welfare and milk production fed on dietContaining hydroponically germinating seeds. Ital.J.Anim.Sci. vol. 8 (Suppl. 2), 634- 636.

Farid, M. F.A., H.M. Abou El-Nasr and N.I. Hassan (1986). Effect of dietary available arbohydrate level on feed and nitrogen utilization in sheep given urea in the drinking water. World Rev. of an0mal Prod., 12:3. 
Fayed, M. Afaf (2011). Comparative Study and Feed Evaluation of Sprouted Barley rains on Rice Straw Versus Tamarix Mannifera on Performance of Growing Barki Lambs in Sinai Journal of American Science, 7(1), 954-961.

Fazaeli H., H. A. Golmohammadi. A. A. Shoayee., N. Montajebi and Sh. Mosharraf (2011). Performance of Feedlot Calves Fed Hydroponics Fodder Barley J. Agr. Sci.Tech. 13: 367-375.

Fazaeli H., H. A. Golmohammadi., S.N. Tabatabayee and M. Asghari-Tabrizi (2012). Productivity and Nutritive Value of Barley Green Fodder Yield in Hydroponic System. J. Agr. Sci. Tech. 16 (4): 531-539.

Goering, H.K. and P.J. Van Soest (1970). Forage fiber analysis. Agricultural Handbook, No. 379, USDA, Washington. DC, U. S. A.

Hathout, M.K and H.M. El-Nouby (1990). Practical application of crop resdues treatment in Egypt. 3rd International Symposium on feed Manufac and quality control, pp, 337-347.

Helal, H. G. (2012). Sprouted barley grains on rice straw and acacia saligna and its effect on performance of growing barki lambs in sinai. Proc. of the $5^{\text {th }}$ Animal Wealth esearch Conf. in the Middle East \& North Africa13: 331-346.

Henry, R.J. (1965). Clinical Chemistry. Principles and technics, P. 293.

Ibrahim, A. Fathia ,Hoda, M. El-Hosseiny and I. M. El- Sayed (2001). Effect of using sprouted barley by recycle process of agriculture residues on feeding value, rumen activity and some blood constituents of crossbred sheep. EgyptianJ.Nutrition and feeds, 4 (Special Issue) 265- 273.

Jackson, M.L. (1958). Soil Chemical Analysis. Constable and Company, Ltd, England.

Kearl, L.C. (1982): Nutrient requirements of ruminants in developing countries. Utah Agric. Exp. St., Utah State Univ. Logan, UT, U. S. A.

Kent-Jones, D.W. and A.J. Amos (1967). Modern Cereal Chemistry. 6th ed. Food Trade Press, London.

Khorshed, M.M. (2000). Different treatments for improving quality of some crop residues used in ruminant nutrition. Ph.D. thesis. Faculty of Agriculture, Ain Shams University.

Kumar, N.U.; S.Singh and D. N. Verma (1980). Effect of different levels of dietary protein and energy on growth of male buffalo calves. Ind. J. Anim. Sci., 51: 513.

Lorenz, K. (1980). "Cereal sprouts: composition, nutritive value, food applications." Crit. Rev. Food Sci. Nutr. 13 (4): 353-385.

MAFF (Ministry of Agriculture Fisheries and Food) (1975). Energy Allowances and Feeding Systems for Ruminants. Technical Bulletin no. 33. London: HMSO.

Mayer, A. M. and A. Poljakoff-Mayber (1975). The Germination of Seeds. $2^{\text {nd }}$ Edition, Pergamon Press, Toronto.

Medjekal, S; Arhab, R.; Bousseboua, H., (2011). Nutritive value assessment of somedesert by-products by gas production and rumen fermentation in vitro. Livest. Res. Rural Dev., 23 (3): 46.

Mohammadi, F., Thanaa and M.M. F. AbdalLah (2007). Effect of four seed sprouts on rice straw and spent mushroom media of rice straw to be 
used as agreen fodder.Egyptian J. Nutrition and feeds, 10 Special Issue: $679-691$.

Mooney, J. (2005). "Growing cattle feed hydroponically," Meat and livestock Australia.

Morgan, J., R.R. Hunter and R. O'Haire, (1992). Limiting factors in hydroponic barley grass production. In the proceeding of the $8^{\text {th }}$ International congress on soil less culture, pp: 241-261.

Mukhopad, Yu. (1994). Cultivating Green Forage and Vegetables in the Buryat.Republic. Mezhdunarodnyi Sel'skokhozyaistvennyi Zhurnal, 6: 51-52.

Norton, B.W. (2003). The Nutritive value of tree legumes. In: Forage Tree Legumes In Tropical Agriculture, Gutteridge R.C and Shelton H.M, (eds). pp.43

Pascual, J. J., C. Fernandez., J.R. Diaz., C. Garcesand J. Rubert-Aleman (2000). Voluntary intake and in vivo digestibility of different date-palm fractions by Murciano-Granadina J. Arid Environ, 45:183-189.

Patton, C.J., and Crouch S. R. (1977). Enzymatic determination of urea by calorimetrically Method Anal. Chem., 49: 464.

Rajendra, P., Seghal, J. P., Patnayak, B. C. and R. K. Beniwal (1998). Utilization of epublic. Mezhdunarodnyi Sel'skokhozyaistvennyi Zhurnal, 6 (1): 51-52.

Resh, H.M., (2001). Hydroponic Food Production, 6th ed., 567 pp., Woodbridge Press, Santa Barbara, CA.

Rodriguez-Mulea, C., Rodriguez, H. E., Ruiz, O., Flores, A., Grado, J. A. and C. Arzola (2004). Use of Green Fodder Produced in Hydroponic System as Supplement for actating Cows during the Dry Season. Proceeding of American.

Salisbury, M.W., C.R. krehbiel, T.T. Ross, C.L. Schultz and L.L. Melton, (2004). Effects of supplemental protein type on intake, nitrogen balance and site and extent of digestion in white face wethers consuming lowquality grass hay. J. Anim. Sci., 82: 3567-3576.

SAS (1998). User guide: statistics version 6, 4th ed., Vol. 2 SAS Institue Inc., Cary. NC. USA.

Shipard, I. (2005). How can I grow and use sprouts as living food? Stewart publishing.

Snow, A.M., A.E. Ghaly and A. Snow (2008). A Comparative Assessment of

Hydroponically Grown Cereal Crops for the Purification of Aquaculture Wastewater nd the Production of Fish Feed. American Journal of Agricultural and Society of Animal Science, 56: 271-274.

Stanhope, D.L., D.D. Hinman, D.O., Everson and R.C. Bull (1980). Digestibility $f$ potato processing residue in beef cattle finishing diets $\mathrm{J}$. Anim ci., 51: 202-206.

Tudor, G., Darcy, T., Smith, P. and F. Shallcross (2003). The Intake and Live Weight Change of Drought Master Steers Fed Hydroponically Grown, Young Sprouted Barley odder (Auto Grass). Department of Agriculture Western Australia. 
Van Hao N. and I. Ledin (2001). Performance of growing goats fed Gliricidia maculata, Small Ruminant Res. 39: 113-119.

Warner, A.C.J. (1964). Production of volatile fatty acids in the rumen methods of Measurements Nutr. Abst. and Rev. 34: 339.

\section{انبـات حبوب الذرة الثـامية على مخاليط سـف النخيل و قشـور البطاطس الجافـة

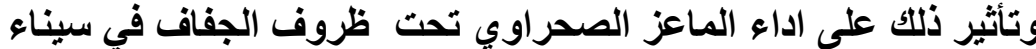

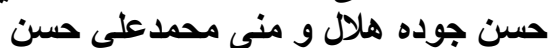 قسم تغذية الحيوان والدواجن, مركز بحوث مدو الصحراء, المطرية, القاهرة, مصر}

هدف الدراسة الحالية الى دراسة تأثنير انبات حبوب الذرة الثامية على مخاليط من سعف النخيل و قنشور

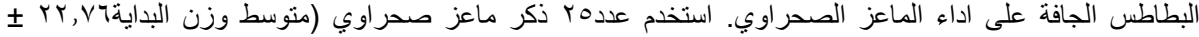

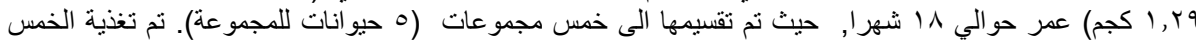

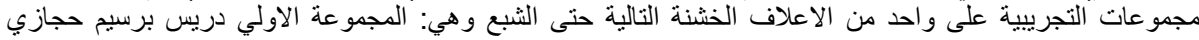

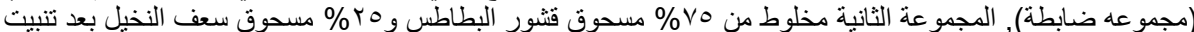

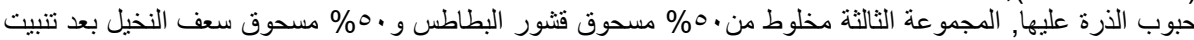

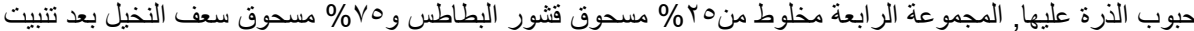

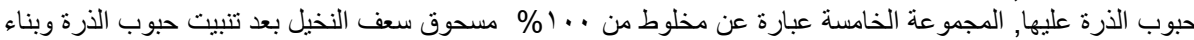
عليه:تم اجراء تجربة تغذية على الماعز استمرت 0؛ يوما, تلتها تجربة هضم لتقدير معاملات الهضم للاعلاف التجريبية الخشنة وكانت اهم النتائج:-

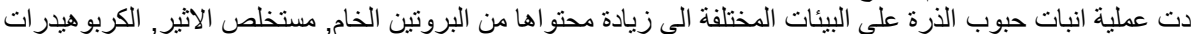

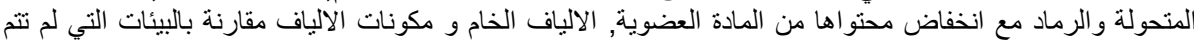

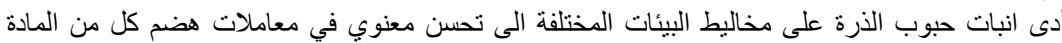

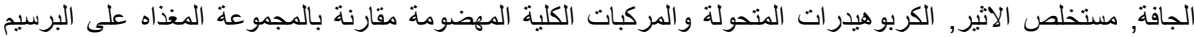

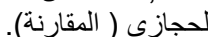

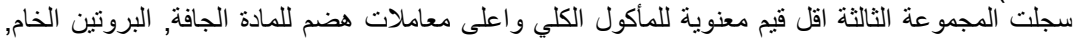

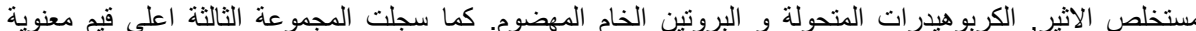

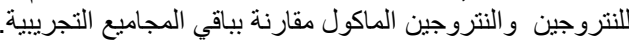

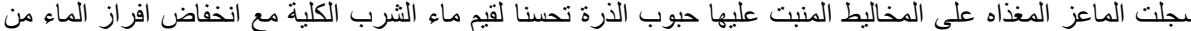

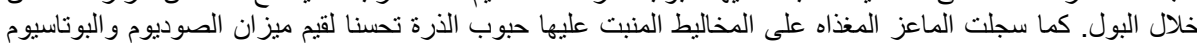

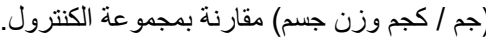

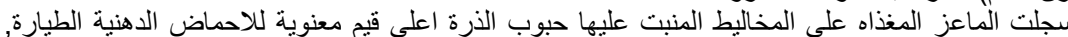

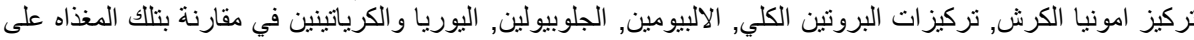

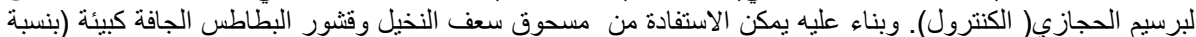

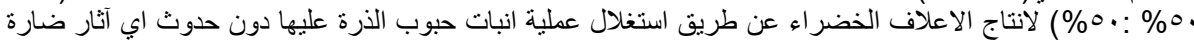
للماعز الصحر اوي والمرباه تحت ظروف الجفاف في المناطق الصحر اوية.

كلية الزراعة - جامعة المنصورة كلية الزراعة - جامعة كفر الثيخ
قام بتحكيم البحث

أ.د / عبد الحميا محمد عبد الحميد

أد اسعيد احمد محمود الديد. 